\title{
The Trojan Horse of Globalizing Media \& Changing Identities in Nigeria
}

\author{
Liwhu Betiang \\ Department of Theatre \& Media Studies, University of Calabar, Nigeria
}

Copyright $\bigcirc 2016$ by authors, all rights reserved. Authors agree that this article remains permanently open access under the terms of the Creative Commons Attribution License 4.0 International License

\begin{abstract}
The Media Convergence Age has witnessed some 'techno-apartheid' or digital divide, mass movements of people, ideas and material culture across geographical borders; all propelled by media technology. Consequently there's 'cultural-browning' among nationalities but specifically in the Nigerian case, deep implications for whatever remains of an 'authentic' national cultural identity. Drawing from literature and empirical observation over the past fifty years within two generations of Nigerians, this study shows how globalization interpenetrates a nation-space; and how it is altering/changing the face of Nigerian nationals, through such globalizing weapons like electronic/media technologies, infotainment programming, televangelism, consumerism, as well as corporate merchandising of material culture. This study becomes significant when seen against the background of Nigerian core cultural values which are being gradually re-negotiated in favour of what may be considered as dominant Euro-American values. This phenomenon portends deep-running implications for a nation state whose peoples are primarily ethnic-bound and fundamentally assertive; caught within an absence of a functional, proactive national audio-visual policy.
\end{abstract}

Keywords Media Globalization, Cultural Identity, Cultural Imperialism, Nigeria

'Melange, hotchpotch, a bit of this and a bit of that is how newness enters the world.'

- Salman Rushdie. Satanic Verses, Quoted by Eck, Breitinger, Theatre and Performance in Africa: Intercultural Perspectives, p6.

\section{Introduction}

The fear or reality of shifting national cultural identities has been pictographically represented by Yukinori Yanagi in his painting The World Flag Ant Farm, which carries 170 coloured sand-poured flags that represent different nations of the world. The appearance of each flag is increasingly altered due to the activity of ants that continually transfer coloured sand grains from one flag to the other thereby creating new national identities [1]. The process of national identity-browning represented by this analogy remains a problem and maybe, hope for the third world 'minority cultures'; in the same way the issue of multiculturalism has become problematic exemplified by the July $22^{\text {nd }} 2011$ Oslo mass killings. This essay articulates how the mass media serve as Trojan horses for globalizing content in Nigeria and how these may be renegotiating perceived national identities in favour of Euro-American imperial models in the face of prevalent arguments that globalization is decentered. Beyond this, what might be the implication of this cultural browning to national cultural engineering in the new millennium?

\section{Evolution \& Dimensions of Globalization}

Globalization has been perceived in different perspectives by different scholars depending on their position in time and space on the globalization grid. Steger [2] likens globalization scholars to the seven blind men of Tugistan who contemplate it from the points of view of politics, culture, environment, economics, religion and ideology; or even deny its existence; hence we have skeptics and hyper-globalizers. Each of these perspectives are interested in specific aspects of the phenomenon; thus: the economists bother about global markets, the historian: global capitalism, the sociologist: diversity and convergence of lifestyles and values; and the political scientist: erosion of state sovereignty [3]. Peng [4] summarizes three perspectives of globalization: "a new force sweeping through the world in recent times; a long-run historical evolution since the dawn of human history", and, "a pendulum that swings from one extreme to another from time to time." He concludes that, "it is, more accurately, a process similar to the swing of a pendulum." Coming from the point of view of global business, he proposes a midway situation: "[semi]globalization [which] is neither to be opposed as a 
menace nor to be celebrated as a panacea;" but that "it is to be engaged." (Peng's emphasis) Thus, the globalization concept, far from befuddling us, we should 'engage' or negotiate with it in the manner of the ants in Yanagi's painting, World Flag Ant Farm.

I proceed from a cultural perspective with a narrower bias to media globalization, which serve as arrow-heads, with the assumption that globalization, which inherently promotes sameness and homogeneity, is an evolutionary and continuing process of cultural imperialism; and, a continuing renegotiation of power relationships between the powerful capitalist west and the third world South [5]. Even if it is not one-directional, whenever the swing is on the side of the third world, it leaves legacies/scars that tend to evolve into deep-running cultivation effects on the host-nations.

Globalization has also been perceived as the current stage of the colonialism-Imperialism continuum. While imperialism allows for worldwide protection of interests and for capitalist-penetration of large economic areas and can be planned and executed from embassies and chanceries through ideological methods, early colonialism requires effective occupation methods [6]. A parallel has also been drawn between globalization and modernization in terms of its process, self-propulsion, and pervasiveness. Internationalization policies represent globalization because these policies present "new relationships of nation states" which in the African context have spawned such acts and buzzwords like the partition of Africa, Structural Adjustment Programmes, Import Substitution, Labour Downsizing, Deregulation and unrestricted capital flows [7], and economic melt-down.

Whereas, the early colonialists employed arsenals such as religion, education, force of arms, ideology, post-modern imperialists use cultural weapons, which are targeted at the mind especially through the linguistic strategy of satellite communication media, the force of capital, and its consumerist values as propagated through the media of television and computer mediated communication. So in the place of early western colonialism's culturizing media of religion and education, is planted imperialism's new transnational capitalism through the linguistic stratagem of satellite communication media, which include the convergent media.

Thus the "cultural dimension of capitalist globalization [...] has been attributed to the power of the media which are responsible for the (contraction) of the world into what is said to be a 'global village"' [8]. For Amin, ancient, tributary cultures have merely been absorbed by the capitalist culture through a process of "economistic annexation". But Khor sums it up that "globalization is what we in the third world have for several centuries called colonization" [9].

The noun "globalization" is said to have entered the Webster's Dictionary in 1961 but its meaning as a "process whereby social relations acquire relatively distance-less and border-less qualities" only became manifest in the last four decades of the $20^{\text {th }}$ century[10]. This situation has been facilitated by new developments in communication technology and the increasing formation of human organizations which operate transnationally as though the world were one borderless social sphere. Scholte identifies various rudimentary manifestations of globalization phenomena in such areas as ecology (global warming and declining biodiversity) production (the rise of multinationals, with subsequent finance and money transfer, stock markets and global currency, etc.). In the military sphere, we have manifestations like global weaponry, spy satellites, regional and global coalitions for so-called strategic defense, etc.; and in human norms like global standards and measures, as well as human rights. There is also an ever-growing awareness of the world as a single place even in the way humanity thinks because of the inter-relatedness of the world today. This in a deep sense is what is called globalism.

Historians argue that distance trade and interaction across Asia between 1000 and $1500 \mathrm{AD}$ sowed the seeds of modern globalization; and that today's global economy has roots in ancient ancestry [11;12]. Lalaya articulates this march of history as the 'three rounds of globalization' : the first being the earliest cross-border trading and fertilization of ideas between India, China, Greece and Rome, including Babylon and Egypt, which led to local interplay of territory and local cultures and goods. The $2^{\text {nd }}$ Round beginning from the $19^{\text {th }}$ century to World War 2 which witnessed the age of colonies, empires and Industrial Revolution and improved Euro-American living standards; with a backflow of Euro-American ideas into Indo-China. He identifies the $3^{\text {rd }}$ Round as today's rise of India and China as a refinement of Euro-American ideas [13].

However, the growing awareness and behavior of man in a global dispensation have also been occasioned by key media events which have over time emphasized globality. These events date back to 1866 with the first permanent trans-oceanic telegraph cable, creation of the International Telecommunications Union, (ITU) in 1865, the invention and beginning of international flight (1919), global radio broadcasting (1930), digital computing (1946), export processing zone (1954), telephone cable link (1956), telecommunications satellite launch (1962), computer networking (1969), direct broadcast satellite (1976), world wide web (1991); and round-the-world fibre-optic link in 1997. The latter was momentous as it signaled the advent of the Internet. These events, like many others, have significantly impacted on the development of an active process of globalization which is more of a late $20^{\text {th }}$ century phenomenon.

From third-world Nigerian economic point of view, globalization is the "integration of national economies through trade and financial interaction", made possible by advancements in technology and telecommunications [14]. This perspective articulates the phenomenon as the fulfillment of the prophecies of Adams Smith and Ricardo's theory of capital and the wealth of nations. Obaseki identifies the formation of the International Bank for Reconstruction 
and Development (IBRD) and the International Monetary Fund (IMF) as central to globalization. These, according to him, were facilitated by the end of the Cold War and the subsequent triumph of market place ethics of competition. The Cold War had slowed down its progress due to protectionism and ideological polarization between the East and West. Other institutions that have provided impetus to economic globalization include the growth of transnational corporations (TNCs) and other multi-lateral bodies like the World Trade Organization (WTO) and the many agreements on trade and tariffs (GATT, etc.).

The evolution of globalization has also been traced to the development of interdependencies in human history which nation states have always been involved like manufacturing, trade and investment. Conceived as a "process of shifting autonomous economies into the global market," Kwanashie [15] sees the Industrial and the Information Technology revolutions as the two biggest propellers of globalization; while interdependencies have further led to a development revolution facilitated by international finance and policy making.

The economists and global business scholars therefore seem to see globalization as a positive process of increased integration of national economies with the rest of the world (in order) to create a more coherent global economy. Its dimensions include capital market and integration, trade liberalization and labour mobility. The economists do not appear to consider globalization as a threat to national economies but as a development elixir that must be handled properly or "engaged". According to Shamsuddeen Usman, (former Nigerian minister of finance and economic planning), "there are no rational alternatives to the reality of the globalization process" [16] and the appropriate reaction to the phenomenon is not "only adaptation but radical transformation"; its reality being demonstrated by the three forces of technology, liberalization and democracy whose effects on global history have been visibly unrelenting.

Cultural studies scholars like political economists, have a slightly different perspective. Frederic Jameson, a Marxist scholar who links post modernism with globalization, sees the latter as the current stage of late capitalism. The first stage was the political triumph of the middle classes when exchange and production took place within the borders of individual advanced countries. Next was the age of monopoly or imperialism which resulted in the carving up of the world into colonial spheres of influence. This second stage was followed by the post-world War II era of decolonization and neo-colonialism, emergence of great multi-national corporations and internationalization of capitalism, all of which have great impact on cultural forms and values. The fourth stage of this evolutionary process was the coming of media technology revolution. In this era, the industrial society is now based on automation and cybernetics (computer, information and scientific research). This era is also typicalized by a growing and relentless commodification, propelled by the forces of the mass media and advertising [17].
Cvetkovich \& Kellner authenticate Jameson's position, observing the interchangeability of the word globalization with modernization, imperialism and westernization [18]. Shohat and Stam rightly argue that even though there can be no first world without a third world and vice versa, and that cultural production goes on all over the world, "some locales enjoy the power to project their cultural products around the world" (emphasis mine) [19], which gives such locales greater advantage over the "others". This unequal domination is characteristic of globalization whose antecedents go beyond the history of colonialism, having been practiced as earlier implied by imperial powers like Greece, Rome, the Incas and the Aztecs. But what is different and new, in this current shade of colonialism, according to Shohat and Stam, is "... its planetary reach, its affiliation with global institutional power, and its imperative mode (and) its attempted submission of the world to a single 'universal' regime of truth and power" [20].

Globalization theory therefore is the climactic moment of the five centuries of colonialism and imperialism, of Europe's self-appointed promethean role of "spreading its people, ideas, goods and political systems around the world" as a model of development [21]. This phenomenon was given impetus by what Anderson calls "print capitalism", the introduction of a common language regime in the print media and film as commonly used in television productions [22] and today by the single universal language of the Internet. Apart from the ability of these media to mould the human psyche and culture, imperial "power (also) resides with those who build, disseminate and commercialize the[se] systems" [23], as can be seen in contemporary operations of global media corporations.

Our society today is therefore being dominated by a group of media conglomerates from powerful nations like the United States, Western Europe, Japan, and lately China, a situation that has continued to entrench the colonial phenomenon of cores/metropolises versus the periphery, which is largely the global South. These new power centres, according to Shohat and Stam now dominate the world through the Group of Seven in different spheres of economics, politics, military, information-technology and culture [24]. Extending the colonization discourse to the realm of indigenous epistemologies and life-forms, Shiva sums it up when he notes that 500 years after Columbus, "a more secular version of ... colonization continues through patents and intellectual property rights (IPRs). The Papal Bull has been replaced by the General Agreement on Tariffs and Trade" [25].* Therefore, the globalization phenomenon appears from every indication that it will continue to increase in dimensionality, intensity and extensity as the march of history progresses.

The foregoing also underlines the centrality of the media in the propulsion of this phenomenon. Apart from media, which Khan calls the technological revolution (Internet and World Wide Web); there are also political-economic liberalization policies under the arrowhead of the World 
Trade Organization. All of these have eliminated physical, temporal and cultural distance between people, fastened/intensified flows across borders but not without cultural consequences [26]. But how these globalizing media subtly penetrate the cultural integrity of a geographically defined third-world nation-state like Nigeria and how national identities have negotiated or engaged this "browning" process is the thrust of the next section of this discussion.

\section{The Globalizing Trojan Horses in Nigeria: Methods}

Nigeria as Sample: Nigeria is considered as the most populous black nation with a population estimate of 168.283 million people made up of about 400 "ethnic nationalities", scattered over an expanse of 923,768 square kilometers. Nigeria has an abundance of natural gas and petroleum which makes her the $2^{\text {nd }}$ largest exporter; as well as a multiplicity of solid minerals that are still largely untapped because of the global drive for oil. However these natural resources have not translated to high human development indices largely because of institutional corruption and the colonially-contrived contradictions of the Nigerian state. For instance, out of the above 400 'ethnic nationalities', more than $60 \%$ belong to what is considered as ethnic minorities. The nation is therefore naturally configured as a plural state with multiple distinct ethnic identities.

The nation inherited the burden of colonial history from Britain having gained political independence in 1960. This colonial attachment and subsequent amalgamation of the largely Moslem northern and Christian southern protectorates in 1914 have been perceived as an unholy wedlock that has spawned many of Nigeria's political problems. These problems first exploded in the 1967-70 Nigerian Civil War; with subsequent decades of politically motivated military mis-adventures into government, massive looting of the nation's coffers by a kleptomaniac leadership and its political class, economic stagnation and social insecurity, leading to alienation of the masses and tribal loyalties, cleavages and politics, insurrectionism and now fundamentalist terrorism.

All of these may have cultivated the suspicions that exist between what has been identified as the "two publics": the ethnic-peoples and the Nigerian state which Zack-Williams (citing Ekeh \& Abdul-Raheem) traces to the failure of the comprador-elite at the bridge-head who, having taken over from "the colonial state may have missed an opportunity to appropriate traditional institutions to discipline society" [27]. This mistrust between the government and its people has also engendered basic failure in policy implementation because of lack of commitment to national ideals and identity. For instance, former president Goodluck Jonathan, confessed that his administration had been infiltrated by the faceless Boko Haram terrorists. All of the other ethnic militant/insurrectionist militias may also be having their respective ethnic blessings. This "politicization of religious and ethnic identities in Nigeria," according to Zack-Williams [28], "connects with the failure to address the all-important question of citizenship." This problematic of the ever-shifting national question and identity is the cross-roads where the Nigerian state is stranded, more than a hundred years after colonial amalgamation in 1914.

Procedure: This study principally depended on participant observation of the writer living in and observing the Nigerian cultural environment for more than 50 years. Beyond this, it also carried out a random survey of 120 persons (60 young and 60 adult) Nigerians spanning two different but related generations of parents and children. The younger population were university undergraduates of 20-30 years who were given open-ended questions which they administered on their parents whose ages ranged from 50-70+. As indicated in the table below, they were also required to closely but informally observe/chat with, and report on their parents' lifestyles to find out how life was some 50-70 years ago. The younger generation (20-30 years) also responded to these questions which have provided a basis for comparison and a way of drawing out some evidence of identity shift under the specific sub-themes below. Most of these respondents were from the Southern \& Middle belts of Nigeria, dominantly Christian, with a few Muslim or traditionalists in terms of religious orientation. The younger generation and the parents sampled here were considered as a sexless unit made up of man \& woman; but who were exposed to globalizing media content/technologies in different ways. In terms of social class, we can only infer that the sampled older generation of Nigerian parents (aged 50-70) who can afford to train their children in the university would fall within lower middle class and above.

The thematic areas of inquiry and comparison were: the use of media and communication technologies, consumerist behavior, patronage of material culture; and, spiritual and moral temperament of the two generations regardless of their sex, class or religious denomination. All of these themes are promoted through media globalization, which most Nigerians are exposed to. An analysis of these responses/observations based on these specified thematic criteria brought out in some qualitative manner, how the average Nigerian has 'changed' over the period of 50-70 years; in terms of the use/access to media and communication technologies, consumption and consumerist behavior, choices and preferences for material culture as well as the shift in spiritual and moral temperament. As much as possible, the sample fairly represented the different ethnic constituents of the country. The table below shows the content of these responses and how the two different generations of Nigerians may have mutated or shifted in their cultural tastes and preferences. It may also be important to note that 'Generation $\mathrm{A}^{\text {' }}$ are parents (male and female) to 'Generation B'. 
Table 1. Lifestyles \& Identities between Two Generations of Nigerians

\begin{tabular}{|c|c|c|}
\hline Attribute/Generation & $\begin{array}{c}1^{\text {st }} \text { Generation: } \\
(50-70+\text { Years old })\end{array}$ & $\begin{array}{l}2^{\text {nd }} \text { Generation: } \\
(20-30 \text { Years old })\end{array}$ \\
\hline $\begin{array}{l}\text { Media Use \& } \\
\text { Communication } \\
\text { Technology }\end{array}$ & $\begin{array}{l}\text { Used poor road network, sometimes depended on signs \& } \\
\text { symbols to communicate, used town-criers, often used } \\
\text { bicycles and trekking for mobility, depended on letter } \\
\text { writing and telegrams for distant communication, had } \\
\text { restricted travelling, since they used lorries, donkeys and } \\
\text { camels as transportation media for long journeys, Black \& } \\
\text { white TV owned by privileged elites, family watched } \\
\text { family programmes like network news together, high } \\
\text { patronage of foreign radio stations/news often as status } \\
\text { symbol, and used landline-telephony. }\end{array}$ & $\begin{array}{l}\text { Heavy dependence on multi-media Internet communication } \\
\text { channels, Enjoyed more foreign content on color TV/Radio, } \\
\text { greater access and movement due to improved roads and } \\
\text { transportation media, Use digitized mobile convergent } \\
\text { telephony, greater use of English language for } \\
\text { communication and inability to communicate in } \\
\text { mother-tongue, enjoy a variety of media technologies, high } \\
\text { patronage of social media, exposure to technologies, } \\
\text { frequent physical mobility, increased presence of } \\
\text { air-conditioned mini-buses for transportation, increased } \\
\text { ownership/use of computers, smart-phones, laptops and } \\
\text { HD-TV, often consumed media-ware in isolation even } \\
\text { when in company, frequent mobility abroad, greater access } \\
\text { to education and reading materials, increased capacity for } \\
\text { self-expression. }\end{array}$ \\
\hline Consumerism & $\begin{array}{l}\text { Commonly used traditional woven fabric/hides, Simple } \\
\text { lifestyle, farming/fishing as main occupations, consumed } \\
\text { natural food, women wore 'George' wrappers/lace blouse, } \\
\text { and wrapper and men: singlet, tight-fitting shirts with } \\
\text { 'Fela-bongo' trousers for young people, wearing of beaded } \\
\text { dresses common, while educated elites and government } \\
\text { workers wore western-style suits, consumed fresh foods, } \\
\text { 'tuwo shinkafa' or fufu from rice, pounded yam or 'amala' } \\
\text { drank local gin, maize 'burukutu' and palm/raffia/cocoa } \\
\text { wines, had fewer lifestyle diseases, high dependence on } \\
\text { seasonal foods due to lack of preservation methods. }\end{array}$ & $\begin{array}{l}\text { Increased patronage of foreign/food variety from eateries } \\
\text { and supermarkets, patronize canned, frozen and fast food } \\
\text { culture, improved farming methods and varieties due to } \\
\text { technology, higher living cost, patronize pop culture and } \\
\text { diverse dress fashions drawn from global culture, increased } \\
\text { access to medication, drugs and psychedelic pills, Increased } \\
\text { availability of designer fast cars; transport hold-ups in } \\
\text { cities, less dependence on farming and more patronage of } \\
\text { imported food and foreign beverages, use of refrigeration } \\
\text { for food preservation, craze for ownership of cars/building } \\
\text { of personal modern/postmodern architectured houses, } \\
\text { consume foreign spices, drinks and meals, including coca } \\
\text { cola and wide variety of carbonated drinks, female } \\
\text { preference for skinny clothes and looks, greater } \\
\text { consciousness of their body-weight. }\end{array}$ \\
\hline $\begin{array}{c}\text { Patronage of Material } \\
\text { Culture: }\end{array}$ & $\begin{array}{l}\text { Enjoyed black \& white photography, generally took pride } \\
\text { in using and listening to music in local dialects, very } \\
\text { meaningful local high-life music or foreign rock \& roll } \\
\text { music or reggae, Catholic church hymns; wearing of } \\
\text { Afro-cut hair style, depended on herbal medicines, enjoyed } \\
\text { traditional cuisines: groundnut/white/draw/ melon soup } \\
\text { with eba/akpu or pounded yam, lived in traditional simple } \\
\text { architectured houses with hand-made thatch/grass roofing } \\
\text { or aluminum roofing for the privileged few. }\end{array}$ & $\begin{array}{l}\text { Enjoy hifi-colour digital pictures and photography often } \\
\text { taken with mobile cameras, enjoy quality foreign fabric and } \\
\text { textile, but listen more to foreign and local music often with } \\
\text { poor content, quality digital TV, greater access to foreign } \\
\text { music/media rap and hip-hop content, high patronage of } \\
\text { foreign designer clothes and consumables, wear } \\
\text { tight-fitting dresses which emphasize nudity or body shape, } \\
\text { use tattooing as body art, live more expensive lifestyles, } \\
\text { like low-cuts for men and weave-on/attachments for } \\
\text { women, high patronage of jean trousers and T-shirts by } \\
\text { both sexes, high prevalence of foreign-copied rap culture, } \\
\text { wearing of artificial dreadlocks, and more creative use of } \\
\text { local fabrics for exotic designs. }\end{array}$ \\
\hline $\begin{array}{l}\text { Spiritual/Moral } \\
\text { Orientation: }\end{array}$ & $\begin{array}{l}\text { More of traditional animistic religious orientation or } \\
\text { conventional Christian denominations, higher } \\
\text { discipline/morality and respect for elders through greeting } \\
\text { and prostration, respected traditional mores, Deep respect } \\
\text { for marriage institution and low divorce rates, lived simple } \\
\text { lifestyle, used traditional herbal medication from } \\
\text { traditional doctors, and often enjoyed } \\
\text { polygamous/polyandrous marriage styles, even though } \\
\text { traditional society censured adultery and incestuous } \\
\text { relationships, which carried heavy cleansing rituals, } \\
\text { western-educated people attended traditional (not } \\
\text { neo-Pentecostal) Christian churches on Sundays; and also } \\
\text { did 'white weddings' as a social necessity. }\end{array}$ & $\begin{array}{l}\text { Pervasive fundamentalist Christianity \& } \\
\text { neo-Pentecostalism/Islam but with little spirituality, little } \\
\text { respect for traditional religion or elders, higher divorce } \\
\text { rates and little or no real respect for marriage institution and } \\
\text { its obligations, no respect for traditional mores and cultural } \\
\text { practices, abandonment of local languages in favour of } \\
\text { English in traditional meetings or worship sessions, } \\
\text { increased patronage of funk-gospel music; and general } \\
\text { disregard for traditional mores, moral standards and } \\
\text { behavior. }\end{array}$ \\
\hline
\end{tabular}

*Source: Field Survey, 2015. 


\section{Discussion}

The above responses are articulated against the backdrop of the following subheads and available literature from other spaces. These four sub-groups become significant when we understand that they penetrate a nation state through media in very subtle cultural ways. They also appear to have had the ability to occasion some subtle forms of 'cultural browning' as can be seen from the table above, principally through increased media participation and consumption; and human flows across time and space. The following discussion deliberately reflects the wider implications of the 'shifts' noted in the table above.

Use of Media \& Communications Technology: Media technology has revolutionized communication during the past decades which has made access to people and information far much cheaper, quicker and easier. These media include television, Internet and its computer mediated mobile communication, the telephone and micro-chip. Emery and Emery have noted that the age of electronic marvels (is) also an age of contradiction; because of the deep "concern that the gap between classes will widen" [29]. Other related media technologies include other paraphernalia of computer-mediated communication. But even though these have positively contributed to the functions and efficiency of mass media, these media have also engendered 'buyouts' financed with the profits from transnational media manufacturers [30]. The corporatization of (global) media has impacted on the very nature of the digital divide and access.

The inflow of these media in Nigeria has necessitated training and retraining of media operatives in the Nigerian broadcast industry; as a way of avoiding being left behind by the info-technology train. This pressure like the on-going efforts at digital migration that failed to take off in 2015 has again put the media organizations under economic stress. Where training or acquisition of new technology is not possible, the result is alienation and the creation of an illiterate and disadvantaged class within the industry. This is also evident in the wider society as there is a relentless digitization in the banking, education and social service sectors. Beyond this, there is an increase in the "dumping syndrome", whereby old outdated media material artifacts are disposed through dumping, commonly visible in the country with the importation of newer digital versions of equipment for the replacement of an analogue generation. As a result, the volume of abandoned equipment in store-rooms of broadcast stations and mechanics' workshops is daily increasing in the same manner as one sees abandoned cars, TV and computer sets in dumpsters crying for re-cycling; a technology which is near-absent in Nigeria.

The pervasiveness of media technology is self-evident. These new communication technologies have also impacted on our world in such negative dimensions like money and drug smuggling, bio-terrorism, bombings and hijacks. In fact, crime multinationals, like the Yahoo-yahoo Boys in Nigeria, have increased just in the same way as other multinational corporations have fast-forwarded the globalization drive [31]. Media technology has also been particularly credited with the fall of the Russian Communist State [32]. In Nigeria, the globalization of crime is rife with gun $\&$ ammunition trade thriving in Nigerian borders. The presence of AK-47 assault rifles is common sight in the Niger Delta area and among criminals who daily besiege the populace; in the same way as bombs and explosive devices have become common fare with the Boko Haram terrorist group in north-eastern Nigeria. The irony of Boko Haram is that even though their very name is a declaration of war against western civilization, they employ this same civilization's technologies to execute their terrorist acts. Most of these cultural artifacts are promoted through ubiquitous globalizing media.

But we need not forget the clear lopsidedness in this Info-technology accessibility in favour of western nations: "80 per cent of the world's population still lacks the most basic telecommunications" for instance as Thabo Mbeki pointed out a decade ago at a February 1995 G7 Conference, that there were more telephone lines in Manhattan, New York than in the whole sub-Saharan Africa and "half of humanity has never made a telephone call" [33]. Development analysts and activists feel that the undue shift to information technology investment also tends to divert attention from the more pressing issues and problems like disease control and hunger and war in some third world countries [34]. Nigeria has her own share of pandemics like HIV/AIDS, malaria, polio (particularly engineered in some parts of northern Nigeria by anti-Western propaganda), and Lead poisoning of children in Nigeria's Nassarawa state. The reliance of the country on foreign donors to address these problems also speaks for its integrity as a truly independent nation.

The foregoing however, does not suggest that there are no positive influences attributable to these new information technologies and globalization as can be seen in the areas of education, research, environment, satellite communications, medicine and health, and access to information.

Consumerism \& Media Programming: Defined as the promotion of consumption as an appropriate orientation, consumerism is primarily used as a marketing strategy to create desires in potential consumers, principally through advertising and other representation to create the feeling that the satisfaction of these desires is a desirable and healthy norm. The medium of television (including mobile smart phones) carries seductive advertisements in 'techni-colour' which glamourize western life styles - "we see many things on TV that we would like to have, and therefore we become greedy", says an Indian villager. Sometimes and more often, these desires cannot be satisfied because of the depressed economic situation thereby creating unhealthy tension in youths especially, who are being exposed to life styles they cannot afford or ever can enjoy. With television, "family and community bonds are being replaced by national and international corporate structures through advertising" [35].

Consumerist advertising has shrunk the world through the 
promotion of a homogenous lifestyle noticeable in clothing; and a certain notion of beauty, food and drinks. This pervasive consumerism also impacts on development, as some development agencies from well-meaning first world are frustrated by consumerist communications strategies by organizations which, as Sharma rightly observes, promote their free market system by “... unloading blatant consumerist values, inappropriate and dangerous economic models, and junked technologies" on their host cultures. According to Sharma, this avalanche of consumerist messages, "promoting seductive models is endangering traditions, local cultures, lifestyles and even habitats and biodiversity" [36]. This happens because many TV programmes, like other media give legitimacy to urbanized life styles and images which traditional societies begin to accept as the desirable norm [37].

Apart from creating desires and depicting false images of glamour and models, consumerism promoted through advertising and 2-way cable television, YouTube, social media and other video text media is traditionally designed to be action packed and impactful. The highly dramatized themes and actions often promote crass materialism, impulse buying, violence and immorality especially in youth, who are always on the vanguard of what they perceive as modernity. In the very same 'global neighborhood' where these values are promoted and consumed, there are also some members of the neighborhood who can ill-afford these and as a result, there arises disaffection in a traditionally cohesive community, thereby causing envy, violence, division and anarchy as well as the emergence of an information under class [38]. Part of the disjuncture and disaffection between the conspicuous-consuming political class and alienated Nigerian youth is the ostentatious lifestyle of new-generation politicians who promote these materialistic values as a lifestyle; and at the same time, use these desire-crazed and impoverished hungry youth to fight their political battles without due compensation. This tendency is part of the root-causes of the many cases of youth restiveness and insurrectionism in Nigeria's Niger Delta, South-eastern or North-eastern Nigeria.

The role of globalizing media technology (television, radio, Internet, smart mobile phone, etc.) in the promotion of consumerism is more monumental because the other media of print and billboards are not as invasive and domineering as these. The West/producers of these technologies have used these globalizing media as desirable Trojan horses to "export[ing] its popular culture, first as images in motion pictures, magazines, music and television and finally as 'franchised' commercial enterprises [39]." This franchise culture has given new impetus to the new pandemic of McDonaldesque fast/junk foods like Mr. Biggs and many others in Nigeria like baby formulae (long discredited by WHO), Coca Cola and jeans clothing as material culture often promoted through consumerist media. Unfortunately, fast food for example, is now being linked to certain life-style diseases in Nigeria; according to Bamimore,
Numerous epidemiological data have supported the notion that increasing westernization and industrialization in human populations, which alter dietary and physical activity patterns, are associated with a greater incidence of chronic degenerative diseases [40].

There is also a relationship between advertisement, media content and popular culture. Advertisers achieve their consumerist ends by using both international and local "icons of pop-culture" to send their messages and they (advertisers) support media that use the 'right' message for their desired audiences [41]. In Nigeria, new convergent media and cable television especially sell audiences and very little programming. For instance mobile telephony inundate telephone services with advertising; while their $3 \mathrm{G}$ Internet services become the super-highway for youths to participate in global social networks like Facebook, WhatsApp, To-Go, You-tube and of course the Black Berry 'BB-Baby' craze among young women. These convergent media artifacts have created a youth class that has become progressively self-centred with anti-social habits as you find them "pinging", texting and "sexting" in company or even places of worship. So while social media have democratized self-expression, ethical control and regulation become increasingly difficult or near-absent. Beyond these, eating habits and food choices, dress styles and personal outlook are being tailored after mass media and advertising models; as it appears the young folk hardly understand the difference between media hype and reality in a post-modernized world where reality apes media representation and vice-versa in confusing copy-cat fashion.

Local media programming is also making its own contribution to this new consumerist orientation. The concept of infotainment, i.e. packaging and communicating information in an entertaining manner is like the sugar-coated pill commonly found in drama and theatre. "Infotainment" is a product of commercial programming in broadcasting. The relationship between entertainment programming, cultural transmission and behaviour change has been a much researched subject. A seminal study by Edward Jay Whetmore [42] represented the findings in what he called the Cone Effect. The study concluded that all entertainment programming exaggerates and magnifies real life in order to make it more entertaining and interesting through a process he terms Constructed Mediated Reality (CMR). This reality is usually created to be sexier, funnier, more intense and colourful than real life. When received by the audience, it is reinterpreted at a perceptual level known as Perceived Mediated Reality (PMR). The PMR differs between audiences because of differing frames of reference. Thus the distortion of cultural reality by writers and programme producers has the effect of creating new cultural realities for audiences whether the formats are news, melodramatic soap operas, docudramas, films or even music.

Nigeria's Nollywood movie industry has become the second largest in the world making its products a 
pre-dominant diet for local and international audiences. Nollywood's output dwarfs whatever comes out of TV programming and also competes favourably with pirated TV soaps from the West. However, the inaccessibility of public TV in Nigeria drives Nigerians into becoming captive audiences for cable TV providers like South Africa's Multichoice DSTV and the new Chinese Star-Times, both of which float dedicated channels for Nollywood movies. These movies are bought off producers through what critics see as unfair deals that leave little profit for practitioners.

In the area of music, one can say that Nigerian musicians have to a large extent domesticated western pop music such that there is little market for other importation. But like the domestication in the home video industry, what is called Nigerian pop is actually western rap or pop with the Nigerian voice; as the form is still western. So while rap music dominates the Nigerian music industry, very few artistes play original songs that reflect what is left of the 'authentic' Nigerian indigenous cultures. This process of glocalization or 'localizing the global' is one post-modern way Nigerian cultural producers have come to terms with globalization. It goes without saying that engaging globalization in this 'glocalizing' manner contributes to the browning process of the Nigerian identity in a postmodern world of fluxes, into a near 'mullato' or hybrid identity. The content of Nigerian movies and pop music videos are creative and eclectic apes of western models.

Various media effects studies ${ }^{2}$ have shown the negative effects of films, radio, television programmes on children \& adults alike especially in content areas such as violence, pornography, obscenity, etc. Other studies have also been done on television violence, sexually explicit Internet content and their effect on children's moral reasoning. Even the Internet, gone viral through mobile applications, has been found to impair academic performance especially with its synchronous communication application as chat rooms, e-mail and use nets, newsgroups and social networking. All these become significant through some subliminal cultivation effect process because human beings, especially impressionable young folk, are prone to become what they watch or hear especially from persons considered as role-models.

Another dimension to infotainment programming is 'infomercials'. This is a programming strategy whereby full-length TV promotional commercial programmes are packaged as news broadcasts, thus giving them some false air of editorial authenticity [43]. A lot of pressure groups have been formed to protest certain product advertising while legislation has been enacted in respect of many products like cigarettes and alcohol in many parts of the world. The global prevalence of 'Big Brother' reality show and their multiple 'info-mercial' clones on television worldwide is a case in point. The Nigerian screens are not short of this newly imported brand which Turner describes as a "demotic turn" whereby media have become some kind of cultural factories for the production of "celetoids" or mass produced celebrities [44]. Every mass pacification industry ranging from beverages, alcohol, and telecoms have become franchisors of this brand.

Even though advertising keeps media organizations on air, it has been much criticized for reasons that it persuades its captive listeners to buy goods and services which they can ill-afford, it uses emotional appeal, it is biased, it contains competitive claims, it is repetitious, vulgar, obtrusive and irritating [45]. In the Nigerian environment like in most competitive media frontlines, advertising becomes the driver of most TV media programming. It becomes most pervasive and intrusive where there is no technology for filtering off consumerist advertising. In fact, advertising has become an integral part of media programming; because even on its own, it is being packaged to provide compulsive entertainment apart from its mind-bending ability. The volume of advertising that goes on during local popular TV shows like European League alone shows how many captives global media networks have made of Nigerians.

Television news has also evolved some new techniques to make its packaging and presentation more entertaining as a way of building audiences, improving ratings and generating higher commercial fees [46]. Sexism is promoted on television news with the preponderant feminization of media by most broadcast stations. Other identified techniques include the practice of 'eyewitness' news reporting, the creating of a friendly atmosphere during presentations, and adopting magazine formats for news packaging to broaden interest and viewership. This media pandemic has assumed viral dimensions as corporate media use these formats to entertain, sell and promote their consumerist products among audiences that are largely media-illiterate.

Material Culture \& Spirituality: On a broader economic level, transnational media corporations propel globalization through trade linkages, integration of world capital markets, increased private flows, direct investment in advanced telecommunications, and labour movement of media operatives through out-sourcing arrangements. It is with all these that many third world economists are tempted to conclude that opening up the market through deregulation has a direct positive effect on national growth [47]. But Nwachukwu \& Ekwe note the paradox that, "while globalization purportedly opens the world market to agricultural goods from the developing countries, farmers in these nations are too poverty-stricken to be able to produce ... [to] meet international standards". As a result, local farmers remain poor; government loses revenue and has little resources to sustainably develop the rural areas [48]. This also applies to media production and tie-in arrangements with regional media groups operating in Nigeria like Multichoice and Startimes, as they buy up and capitalize on local media products and at the same time serve as purveyors of western consumerist programming.

Axtmann rightly argues that global culture is western and globalization is western cultural imperialism. Even if national cultures become progressively more heterogeneous 
than homogeneous, cultural globalization remains a kind of influence, even if with a local attachment and coloration [49]. This phenomenon however ensures that cultures being dynamic, "do not become static but remain 'fields of struggle' on which they are constructed, deconstructed, and reconstructed" [50]. But the centrality of media in shaping identities and change has been reiterated and re-emphasized which makes it important to re-examine the various globalizing agents on our electronic media; as the mass media propagate and foster colonial and alien models. This happens at different levels of media technology, form and content: whether it is video cassettes and CDs, DVDs, mobiles and their many applications and content sharing capabilities, films, television series and serials, news, pop music or dress codes and styles which have become models for many Nigerians.

Another potent media globalizing agent is the manner media practitioners use English language on Nigerian radio and $\mathrm{TV}$, which has dominantly evolved into something more Americanized or Anglicized than Nigerian. The Columbian pop-star, Shakira once remarked that she had to adopt the English language in order to break the frontiers between cultures and to launch herself into the global music market; and as a way of integrating her two (local and international) audiences [51]. This kind of language hegemony is heavily promoted by new convergent media, global media corporations, disc-jockeys, film/video stars and musicians who unfortunately also provide role models for younger listeners, who incidentally are the 'authentic' nationals of our collective tomorrow.

In Nigeria, like Ssewakiriyanga notices in Uganda, "TV and radio stations are in the mainstream in promoting these 'western genres', and "music has subverted the notion of national boundaries" [52]. Fingering the youth as the precursor of this trend, the music genres that are popularized by the electronic media include rap, reggae, raga, hip-hop and pop. These brands of music share common characteristics: "expressive vulgarity, sexual resonance, preposterous violence and good-times [consumerist] symbolism"; moreover, the Afro-American film and pop-stars have become icons for the youth who, "... imitate their actions, language use, accent and fashion, including ideas perceived as authentic rather than a mere sham" [53]. Ssewakiriyanga blames the rise of these popular genres to government's embrace of liberalization policies and the mass media; concluding that the video, television and radio, as forms of cultural production, have begun to challenge the notion of the nation state and nationality.

This is only additional to the ever-increasing ubiquity of commercial global media corporations (including public service BBC) whose off-shore stations now broadcast in almost everybody's backyard through satellite Frequency Modulation channels. With new media distribution platforms and packages like mobile telephony broadcasting, internet audio/video streaming, narrow-casting and podcasting, social media, radio and TV have truly become ubiquitous. Media advertising has fostered consumerism which has affected all aspects of national culture. Apart from the changing lifestyles (e.g. dressing, language mannerisms, media content \& technology consumption, etc.) it has also encouraged an influx and use of telecommunication and electronic material culture artifacts. These include increased patronage of cable and satellite stations with their heavily westernized programming and disc jockeying, increased telethon/radiation programmes with talkback facilitated by GSM communication, increased international news content in programming, repackaged or domesticated rap music; and the growing use of miniaturized digital radios, Walkman and CD players, i-pads and i-pods, PDAs as well as karaoke/VCD music even on local public networks and stations. The software for most of these media artifacts can be pirated or downloaded as Applications or 'Apps' without charge. Unfortunately, the West, according to Isola [54] pushes for an open market in the third world for its goods, equipment and culture but show intolerance towards African cultures and third world goods.

In the area of spirituality, tele-evangelism becomes another arena of contest. Osterhammel [55] has articulated how the colonial process used the cultural area of religion to destroy indigenous religions. As receptive as these indigenous religions were to the intrusion of Christianity and Islam, these religions quoting Bishop Matthew Kukah turned around to destroy not just their host religions but the African culture. Isola identifies these "neo-Pentecostal movement(s), the born-agains in Nigeria", as the "dangerous victims of globalization" [...] who, "use American type gospel music and prefer to speak English with the American accent as they ensnare their congregation with their "gospel of prosperity" [56] on public radio and television channels. Prosperity bounty has now been engrafted into the spiritual sphere of the Nigerian existence; which on its own has changed the typical Nigerian outlook on material life and spirituality.

Beyond this, neo-Pentecostals attack African culture and even African names, with an exorcist's zeal and see no difference between faith, religion and culture, as they turn the younger generation from their heritage. The illiterate masses, which have an enlarged capacity to tolerate, have become apathetic as the political and 'cultural elite' who pose as change agents continue to take their models from their master's abroad [57]. Cheap Christian music has become popular fare in Nigeria so much so that it begins to replace secular or folk spirituals in public gatherings. It is common sight to hear performances and songs that shamelessly proclaim: 'I don't change my name to God-win', (meaning: 'I have changed my name to God-has-won'); in other words, changing the traditional names to foreign Christian-Islam names has become more politically and spiritually corrects for many a Nigerian.

The master copy of tele-evangelism remains the USA. Tele-evangelism or electronic church dates back to the 1950s in the USA when TV began to reduce attendance at tent revival shows. Its forerunners like Oral Roberts took the church to the television. Pioneered by such 'evangelists' like Pat Robertson, (owner of CBN) James Robinson, Robert 
Schuller and Oral Robert, tele-evangelism in the USA has been steeped in financial and criminal controversies; just in the same way as it has been in Nigeria with the controversial press wars and scandals between Pastors Kris Okotie and Kris Oyakhilome, about the sources of their stupendous wealth and pastoral powers [58]. Today, the number of neo-Pentecostal churches in Nigeria is beyond quantification as church businesses have become the easiest business to operate since they come as NGOs which are tax-free. They exploit the gullible disposition of both the government and the economically depressed Nigerians desperate for re-assurance from bounty-harvesting prophets and pastors.

It is noteworthy that these religious groups also run the highest number of channels on free-to-air cable TV on the Nigerian airwaves. In the absence of regular public service TV and the high subscription rates for cable, Nigerians have little choice but become captive audiences for miracle churches on the airwaves. It is not unlikely that the much vaunted, possibly satirical public posture of Nigerians as the "most religious and happiest people on earth" is not unconnected with the suffusion of such religious fare on all media; and in the uncountable litter of such establishments which daily draw sanctimonious membership that is progressively confounded and driven by a depressed economy and social insecurity.

\section{Conclusions}

The foregoing discussion has tried to identify some of the media through which the homogenizing and disruptive phenomenon of globalization gets at the heart of our national and cultural identities. There are however other identifiable influences which include consequent breakdown of family bonds, increased western individualism and immorality, homogeneous lifestyles in clothing, food and even general ideas of aesthetics and correct language. There is also the growing religious and cultural and ethnic fundamentalism among the alienated youth due to widening gaps between the poor and the rich, endangered cultural biodiversity and browning of local colour; as well as neo-Pentecostalism with its attendant demonization of traditional cultural patterns, child-naming and behaviour, and the 'creolization of local languages because of the hegemonization of English language' [59]. Celebrating Channel 0's $3^{\text {rd }}$ Anniversary in October 2000, a news reporter proudly announced that "the channel has achieved their desired status: (sic) the VJs have become Pan African role models" [60]. One only needs a glance at the programme content of Channel 0 to appreciate the pithy depth of this obviously harmless statement.

Without regressing into the emotive aesthetics of negritudism, the traditional identity of the African before the erosive colonial contact was synonymous with such cultural values that were anchored on humanity, sociality, altruism and unpolluted morality. Other identifiable characteristics included the now postmodern 'live-and-let-live' moral philosophy, respect for elders and the worth of man, as against the idolism of material things; as well as wholesome human relations, as a reflection of man's relationship with the Supreme Being, moral reservation towards exploitative tendencies and emotional openness [61]. These humane characteristics coupled with other intangible aspects of traditional African culture (as reflected in language for instance) gives the African a uniqueness "like no other man", even though the African is like all other men in all other respects.

Nigeria as a nation has not recovered from the identity conflicts created by the contradictions of her coloniality and post-coloniality. Layiwola rightly notes that the Nigerians' pre-and post-colonial identities are still in the process of "...mixed inculturation in which people mingle to recreate, re-negotiate and re-aggregate insularity, notional purity or ethnic supremacy" [62]. But the paradox of globalism as Layiwola has noted, has a way of emancipating the oppressed through this same unequal relationship and imbalance by creating centrifugal forces which drive towards new territorialities and balance. Mann sees these forces as emanating from "the post-modern institutional problem with the global setting and the modern problem within the local setting" [63].

The engagement with the problem of changing identities may lie in this post-modern contradiction. The remediating actions must be found in the direction of strengthening the local colour within this 'browning' process. The threat of cultural homogenization, according to Cvetkovich, has led to increased multi-culturalism, multi-lingualism and hybridization through "global forces [which] can be oppressive" and capable of eroding cultural traditions and identities. But rightly adding that "they can also provide new material to rework one's identity and can empower people to revolt against traditional forms" [64]. But all these can only be given effect if managers of Nigeria's national 'third culture' with the leadership of the intellectual cultural elite provide the requisite enlightened direction coupled with a reversal of the prevalent unwitting acceptance of globalization as the Promethean elixir for third world development.

Other re-negotiation strategies may include the revitalization of local languages through reintegrating them into the primary education system; massive retrieval of endangered local oral culture, dance and festivals through audio-visual technology; greater honest commitment to our cultural values by managers and operatives of our mass media institutions, as well as finding a way to regulate what Isola calls "ignorant men of God" from leading the Nigerian youth astray, away from their culture [65]. Cultural managers and governments are being urged to take advantage of the resources of UNESCO's roadmap towards preserving cultural diversity.

Like the popular practice of adaptive technology, glocalization or inculturation can be encouraged along given policy lines in respect of positive foreign models or influences that are compatible with Nigeria's indigenous cultures. A more proactive cultural policy, which is drawn 
from local cultural resources and strengths with honest implementation, and not just a document to satisfy UNESCO/Western requirements, could be designed for the country. The existing policy, which lacks grass root structures and participation as well as sustainable cultural financing provisions, needs to be revised and updated. A policy that encourages a bottom-up grass-root cultural production, consumption and development will do much to retrieve and redefine the fast-fading identity of our local and national cultures.

A Nigerian national project identity can be consciously engineered and pursued within a national cultural policy framework; while local indigenous cultures are encouraged under a given national cultural direction. This can be promoted through the same mass/convergent media (like public service broadcasting and new media), which have so far given undue promotion to foreign cultural values, and are often mercantilist in nature. 'We should protect our cultural heritage to positive effect', like Ajumogobia puts it, because, 'culture can [only] play such a role if it is authentic' and not driven by the 'lure of commercial success'; which may have 'contributed in some measure to some of the prevailing negative images of Nigeria' [66]. Like Yanagi's World Flag Ant Farm above, we now live in a world of interconnectivity, cultural browning and natural symbiosis; but, whose beauty will lie more in a rainbow-like cultural difference and configuration than a homogeneity bereft of its diversity and individual local colour.

\section{Notes}

${ }^{1}$ This paper benefited from the very useful contributions of members of my ROAPE Writing Group under the direction of Professor Alfred Zack-Williams of Education and Social Science Department of the University of Central Lancashire, in the April 2012 Accra Round of the Nairobi Process. Many thanks.

${ }^{2}$ Other studies include: Payne Fund Studies (1929), Hadley Cantril Study (1938), Paul Lazarsfeld Study (1939,) which show the negative effects of films, radio, television programmes on children $\&$ adults alike especially in content areas such as violence, pornography, obscenity; and, Cynthia Hoffer et al, on television violence (283-99), Wei Wu and Soh Hoon Koo on sexually explicit Internet content (260-74), Marina Krcmar and Mark C. Cooke on children's moral reasoning and television violence (300-316); Kirk Johnson's study of mass media and their total effect on rural Indians (147-9); the Internet and academic performance (Kulby et al 366-82). Levin and Carlsson-Paige, (Gorham 12-13) have also shown how TV productions undercut children's healthy growth and basic developmental concerns (Annual Editions 12-18). Media globalization on its own has also impacted on management of national/local broadcasting (cf. Betiang, 2009); also, my preliminary thoughts on the effect of globalization and cultural development and identities (Betiang, 2006).
*See also Vandana Shiva, 'The Polarized World of Globalization' in response to T. Friedmans' argument of a new homogenous 'Flat World'; where Shiva argues that corporate globalization polarizes and divides people along economic classes, religion and culture, gender, geographies and religion, labour and capitalism; and by such distortion of the 'web of life' of community, local economics and cultures, has occasioned global convergence of three violent trends: primitive accumulation, culture wars and militarized warfare (www.globalpolicy.org/globalization).

\section{REFERENCES}

[1] Fiero, K. G. The Humanistic Tradition: The Global Village of the $20^{\text {th }}$ Century. Vol.6, $3^{\text {rd }}$ ed. New York: McGraw-Hill, 1998, p.158.

[2] Steger, M. B. Globalization: A Very Short Introduction. Oxford: Oxford UP, 2003, p.15.

[3] Khan, K. (www.globalpolicy.org/globalization). Accessed: $24^{\text {th }}$ Oct. 2015.

[4] Peng, M. W. Global Business. Australia: South-Western, 2009, pp. 12-3.

[5] Amin, S. 'The Challenge of Globalization'. Africa and the Challenge of Development: Essays by Samir Amin. Ed. C. Uroh. Ibadan: Hope, 1998, p. 104.

[6] Osterhammel, J. Colonialism: a Theoretical Overview: Trans. S.L. Frisch. Princeton/Kingston: Markus \& Ian Randle, ND, p. 22.

[7] Cooper, F. 'What Is the Concept of Globalization Good For? An African Historian's Perspective.' African Affairs, 100.399 (2001), p 208.

[8] Amin, p.115.

[9] Scholte, J. A. The Globalization of World Politics. London: Macmillan, 1999, p.157.

[10] Scholte, p.14.

[11] Lockard, C.A. 'Seeds of Globalization.' Online. Microsoft Encarta, 2008, p.8.

[12] Bentley, J. H. 'The Roots of Our Global Economy.' Traditions and Encounters: A Global Perspective on the Past. JH Bentley. Microsoft Encarta, 2008.

[13] Lalaya, O. (www.globalpolicy.org/globalization). Accessed: $24^{\text {th }}$ Oct. 2015.

[14] Obaseki, P. J. 'Policies and Strategies for Dealing with the Problems of Globalization.' Globalization and Nigeria's Economic Developments. Seminar Proceedings. Ibadan: The Nigerian Economic Society, 1994, p.66.

[15] Kwanashie, M. 'Concepts and Dimensions of Globalization.' Globalization and Nigeria's Economic Development.' Seminar Proceedings. Ibadan: The Nigerian Economic Society, 1994, p. 15.

[16] Usman, S. 'Implications of Globalization for the Nigerian 
Economy.' Globalization and Nigeria's Economic Development. Seminar Proceedings. Ibadan: The Nigerian Economic Society, 1994, p.47.

[17] Nak-Chung, P. 'South Korea as Social Space: Interview with Frederick Jameson.' Seoul, 28 October 1989. Global/Local: Cultural Production and the Transnational Imaginary. Eds. R. Wilson \& W. Dissanayake. Durham, NC: Duke UP, 1996, pp. 351-53.

[18] Cvetkovich, A. \& Kellner D. 'Introduction: Thinking Global and Local.' Articulating the Global and the Local: Globalization and Cultural Studies. Eds. A. Cvetkovich \& D. Kellner. Colorado: Westview, 1997, p.3.

[19] Shohat, E. \& R. Stam. 'From the Imperial Family to the Trans-National Imaginary: Media Spectatorship in the Age of Globalization.' Global/Local Cultural Production and the Transnational Imaginary. Eds. R. Wilson \& W. Dissanayake. Durham NC: Duke UP, 1996, p.147.

[20] Shohat \& Stam, p.151.

[21] Shohat \& Stam, p.152.

[22] Quoted in Shohat \& Stam, p.153.

[23] Shohat \& Stam, p.166.

[24] Shohat \& Stam, p.147.

[25] Shiva, V. Biopiracy: The Plunder of Nature and Knowledge. Boston, Massachusetts: South End Press, 1997, p.2.

[26] Khan, K. (www.globalpolicy.org/globalization). Accessed: 24th Oct. 2015.

[27] Zack-Williams, A. 'Five Decades On: Some Reflections on 50 Years of Africa's Independence.' Review of African Political Economy 39.131 (2012), p.3.

[28] Zack-Williams, p.1.

[29] Emery, M. \& Edwin Emery. The Press and America: An Interpretative History of the Mass Media. $8^{\text {th }}$ ed. Boston: Allyn \& Bacon, 1996, p.577.

[30] Emery \& Emery, p.593.

[31] UNESCO Human Development Report, p.8.

[32] Wilson, S. L. Mass Media/Mass Culture: An Introduction. New York: McGraw-Hill, 1992, pp.55-6.

[33] PANOS. 'The Internet and the South: Superhighway or Dirt Track?’ Media Briefing, (1995), p.16.

[34] PANOS . 'Trading in Futures.' Media Briefing 31 (1998).

[35] Quoted in Johnson, K. 'Media and Social Change: The Modernizing Influences of Television in Rural India.' Media, Culture \& Society 23 (2001), p.152.

[36] Sharma, L. K. 'TV Dinners.' Development (3 ${ }^{\text {rd }}$ Quarter 1998), p.33.

[37] Johnson, p.154.

[38] Johnson, 60-1; also, Tubbs, S.L. \& S. Moss. Human Communication. New York: McGraw-Hill, 1991, p.12.

[39] Wilson \& Dissanayake, p.41.
[40] Bamimore, M.A. 'Healthy Living: Brain Health.' $5^{\text {th }}$ Distinguished Academic Lecture, University of Calabar Graduate School, 2012, p.10.

[41] Annual Editions, p. 176.

[42] Wilson, pp. 410-11.

[43] Wilson, p.379.

[44] Turner, G. 'The Mass Production of Celebrity: 'Celetoids' Reality TV and the 'Demotic Turn.' International Journal of Cultural Studies 9.2 (2006), pp. 153-65.

[45] Agee, W., Ault P.A. \& Emery E. Introduction to Mass Communication. $9^{\text {th }}$ Ed. New York: Harper \& Row, 1988, pp.360-61.

[46] Wilson, pp. 255-56; also, Ytreberg, E. 'Ideal Types in Public Service Television: Paternalists and Bureaucrats, Charismatics and Avant-Gardists.' Media, Culture and Society 24 (2003):pp. 759-74.

[47] Nzekwu, G. 'Contemporary Experiences in Globalization.' Globalization and Nigeria's Economic Development. Seminar Proceedings. Ibadan: The Nigerian Economic Society, 1994, pp. 29-43.

[48] Nwachukwu, I., \& K. C. Ekwe. Eds. Globalization and Rural Development in Nigeria. Umudike: Extension Centre, Michael Okpara University of Agriculture, 2011.

[49] Axtmann, R. 'Collective Identity and the Democratic Nation-State in the Age of Globalization.' Articulating the Global and the Local: Globalization and Cultural Studies.Eds. A. Cvetkovich \& D. Kellner. Colorado: Westview, 1997, p.36.

[50] Axtmann, p.37.

[51] Quoted in Peng, pp. 512-3.

[52] Ssewarkiryanga, R. 'New Kids on the Block: African-American Music and Uganda Youth.' CODESRIA Bulletin 1 \& 2 (1999), p. 24.

[53] Ssewarkiryanga, p.25.

[54] Isola, A. Limits of Tolerance: The Future of African Culture. Nigerian National Merit Award Winners Lecture, Calabar, 2003, p.22.

[55] Osterhammel, pp. 95-104.

[56] Isola, p.18.

[57] Isola, p.19.

[58] 'Pastor of Thieves.' The News 20 (2003), pp. 22-27; also, Vanguard (June, 2001), p.7.

[59] Oni, D, S. Gupta, T. Omoniyi, E. Adegbija, \& S. Awonusi. Eds. Nigeria and Globalization: Discourses on Identity Politics and Social Conflict. Lagos: Centre for Black and African Arts and Civilization, 2004, p.12.

[60] 'Channel O turned 3 in October 2000.' Africa Film \& TV Magazine 28 (2001), p.8.

[61] Sofola, J. A. African Culture and the African Personality: What makes an African Person African? Ibadan: African Resources, 1978, pp.1-10. 
[62] Layiwola, p.xiv.

[63] Folorunso, F. 'Information Technology and Post-Colonial Africa.' Understanding Post-Colonial Identities: Ireland, Africa and the Pacific. Ed. D. Layiwola. Ibadan: Sefer, 2001, pp. 213-31.
[64] Cvetkovich, p. 10.

[65] Isola, p. 31.

[66] Ajumogobia, Henry Odein, 'Looking Forward: An Interview.' Nigeria at 50:1960-2010. Jeremy Gaines. NP: Shell, ND, pp. 223 . 